\title{
A palavra viva de Mia Couto
}

\author{
Everton Fernando Micheletti \\ Universidade de São Paulo (USP), São Paulo, São Paulo, Brasil \\ efmicheletti@gmail.com
}

DOI: http://dx.doi.org/10.21165/el.v46i3.1630

\begin{abstract}
Resumo
Este artigo propõe analisar algumas narrativas do escritor moçambicano Mia Couto, especialmente o romance Terra sonâmbula, com ênfase no processo entre as tradições orais e a escrita literária. Couto traz alguns aspectos das tradições orais africanas para suas obras, tanto nos temas como na estrutura textual, resultando em uma transferência de valor de uma para a outra. A principal referência é o texto "A tradição viva" de Hampaté Bâ, que apresenta o valor e a força da palavra para vários povos africanos. As outras referências consistem em autores dos estudos da linguagem, do pós-colonialismo e das literaturas africanas em português.
\end{abstract}

Palavras-chave: Mia Couto; literatura moçambicana; tradição viva; tradições orais; linguagem.

\section{The living word of Mia Couto}

\begin{abstract}
This paper aims to analyze some narratives of the Mozambican writer Mia Couto, especially the novel Sleepwalking land, with focus on the process from oral traditions to the literary writing. Couto brings some aspects from African oral traditions to his oeuvres, both in the themes and in the textual structure, resulting in a transference of value from one to the other. The main theoretical reference is the text "The living tradition" by Hampaté Bâ, which presents the value and force of the word to many African people. The other references consist of authors from language studies, post-colonialism, and African literatures in Portuguese.
\end{abstract}

Keywords: Mia Couto; Mozambican literature; living tradition; oral traditions; language.

\section{Introdução}

O trabalho com a linguagem na literatura de Mia Couto chama a atenção há bastante tempo, havendo um grande número de pesquisas sobre suas criações e recriações linguísticas. $\mathrm{O}$ autor, porém, não se preocupa com a língua apenas na forma, mas também como tema, como algo de importância maior para grande parte de seus enredos, principalmente nos romances. Entre as características identificadas em suas obras, nesse sentido, estão as relações entre tradição e modernidade, em que o autor procura trazer aspectos próprios das tradições orais africanas para a escrita, resultando em transferência de valor de uma para a outra.

Desse modo, a escrita, mantendo valores da oralidade, adquire uma força que a torna parte do espaço, da nação moçambicana, da própria terra, como está representado metaforicamente em alguns romances, quando a escrita se faz no chão ou páginas se transformam na própria matéria terrestre. Neste artigo, portanto, apresenta-se uma análise do valor da palavra - das tradições orais à escrita - em alguns romances de Couto, com destaque à Terra sonâmbula, partindo do conjunto de pesquisas já realizadas para avançar em outras possibilidades de compreensão do estilo do autor. 
O principal referencial teórico é o texto "A tradição viva", de Hampaté Bâ (2010), que trata do valor e da força da palavra para diversos povos africanos, aspecto fulcral à análise das obras. Notando-se algumas possibilidades de convergência, somam-se outros autores e conceitos, como a "metáfora viva", de Ricoeur (2005) e o "diálogo", segundo Bakhtin (2011). Os demais referenciais teóricos e críticos consistem em autores que se dedicam às características da linguagem literária, como Lotman (1978), ao póscolonialismo e às literaturas africanas de língua portuguesa.

\section{A palavra viva como tema}

Narrar pode ser uma forma de sobrevivência quando se está em uma situaçãolimite, sob o risco de morte, como acontece com Sherazade, em As mil e uma noites. Nas obras de Couto, em que se tem, principalmente, o contexto da guerra pós-Independência em Moçambique e suas consequências após o acordo de paz, há personagens que contam histórias, como uma forma de resistência. Em Venenos de Deus, Remédios do Diabo: as incuráveis vidas de Vila Cacimba (2010), por exemplo, as personagens se sentem isoladas e esquecidas na vila em que moram, abandonadas em meio a uma epidemia. Por isso, quando chegam ao lugar, os visitantes são enredados por uma série de histórias em que se misturam verdades e mentiras, até que, em determinado momento, uma personagem assume o motivo: "esta terra mente para viver" (COUTO, 2010, p. 181).

Há, no entanto, mudanças nas formas de contar, em que estão implicadas as tensões entre tradição e modernidade, de que faz parte o processo que passa da oralidade à escrita. Em Um rio chamado tempo, uma casa chamada terra, são cartas que mantêm um elo, uma "ponte" entre a velha e a nova geração (COUTO, 2003, p. 126). Nesse romance, uma personagem afirma que se pode conhecer "a vida de um homem pelo modo como ele pisa o chão. Tudo está escrito em seus passos, os caminhos por onde ele andou", concluindo-se que a "terra tem suas páginas: os caminhos" (COUTO, 2003, p. 20). A metáfora contém o processo de mudança, em que aquela terra das tradições orais passa a incorporar a escrita. Assemelha-se ao desfecho de Terra sonâmbula, quando os cadernos de Kindzu tornam-se "páginas de terra" (COUTO, 2007, p. 204).

Após o colonialismo e com a guerra que se seguiu à Independência, há personagens ameaçadas o tempo todo pela morte, como Gaspar em Terra sonâmbula (2007). O menino seria enterrado vivo por Virgínia, anciã que acredita ser melhor morrer do que viver no país que vem sendo tragicamente destruído. Um grupo de crianças intervém e a faz parar, com a seguinte justificativa: "Para ele nos contar a estória dele" (COUTO, 2007, p. 163), assim, ele sobrevive. Em outra parte da obra, um pequeno pastor conta uma "suave estória" que é considerada uma "dádiva de magia" (COUTO, 2007, p. 178). Há, nesse momento, uma valorização das histórias, visto que Muidinga dá, em troca do que ouviu, um amuleto.

Nesse romance, o ancião Tuahir e o menino Muidinga, ao se deslocarem em razão da guerra, passam a viver em um machimbombo (ônibus) destruído e abandonado em uma estrada, onde encontram os cadernos de Kindzu. A leitura é realizada, sendo recriadas as tradições orais, mas em uma inversão. De modo diferente do que se fazia antigamente, quando os anciãos reuniam os jovens e contavam as histórias, quem lê os cadernos é o menino. De acordo com Fonseca, "o velho reaprende as tradições cultuadas pela voz que, agora, lê as letras", configurando uma "interação entre o velho e o novo", em que "a letra recupera o espaço da voz e dos gestos e registra os rituais que a guerra e 
os novos tempos vão tornando impossíveis" (FONSECA, 2003, p. 68). Simbolicamente, Tuahir e Muidinga têm as histórias de Kindzu como um alimento, uma vez que era isso que procuravam na mala quando encontraram os cadernos. Isolados no ônibus, sob os riscos da guerra e da fome, a leitura dá um sentido a suas vidas, tornando-se uma forma de sobrevivência. Ao mesmo tempo, funciona como iniciação para o jovem, que passa por uma aprendizagem, por meio dos acontecimentos narrados.

Couto traz para escrita certos valores das tradições orais, destacando a força que se atribui à palavra, a sua importância como característica humana, como um recurso diante da desumanização causada pela guerra. Com a situação do país em ruínas, em que é difícil transitar, haja vista o ônibus destruído, a palavra torna-se veículo, ela garante alguma forma de resistência e guarda as chances de uma recuperação futura. Nesse sentido, acontece a limpeza do ônibus. Tuahir conta que havia trabalhado em uma estação de trem e que quer cuidar do mesmo modo do ônibus. Decide fazer uma limpeza e pede ao menino para ler os cadernos em voz alta:

Então, o velho improvisa um xipefo [lamparina], solta um pano vermelho. Apanha um ramo de palmeira e inventa uma vassoura. Varre o interior do machimbombo enquanto canta. O miúdo desfolha os cadernos sorridente. O velho se recriava, igual ao seu antigo emprego. E é como se o próprio Muidinga estivesse sentado na estação, aguardando o próximo comboio. Tuahir vai juntando os resíduos do queimado numa velha tampa. Depois, sai do autocarro e espalha as cinzas pelas terras em volta.

- O que está a fazer, tio?

- Estou semear este adubo. É para amanhã quando chover. Continue, filho. Não pare de ler. (COUTO, 2007, p. 139, grifos do autor).

A limpeza se mostra como uma forma de esperança, o que se confirma com o ato de semear. Tuahir utiliza um ramo de palmeira enquanto ouve a leitura dos cadernos, sendo que o nome de Kindzu vem dessa árvore. Há, portanto, uma reunião de forças em torno de Kindzu. Com o espaço tomado pela morte por causa da guerra, as palavras escritas e lidas - oralizadas -, relacionando-se à vegetação e à terra, tornam-se, segundo Moraes, "matéria produtora de vida" (MORAES, 2009, p. 25). Vale lembrar que, de acordo com Eliade (2010, p. 15), há uma "modalidade do sagrado incorporado na vegetação" pela "regeneração rítmica", pela "vida inesgotável" que nela "está concentrada" (2010, p. 15). Quanto aos "resíduos do queimado", remete ao fogo que purifica e que, ligado ao ar, conforme Durand (2011, p. 176), relaciona-se à palavra divina.

O romance se aproxima, assim, da perspectiva do valor da palavra para Hampaté Bâ. Segundo as tradições orais de alguns povos africanos, o ser humano "está ligado à palavra que profere. Está comprometido por ela. Ele é a palavra, e a palavra encerra um testemunho daquilo que ele é" (HAMPATÉ BÂ, 2010, p. 168, grifo do autor). Kindzu apresenta nos cadernos um testemunho que, apesar de escrito, tem a oralidade recuperada pela leitura, culminando nesse momento da limpeza em que a palavra recupera sua força de transformação, de fazer renascer, sendo recorrente no romance, como afirma Moraes, "a atribuição de poderes de regeneração à palavra" (MORAES, 2009, p. 26).

De acordo com a tradição bambara do Komo, como exemplifica Hampaté Bâ, a palavra "é uma força fundamental que emana do próprio Ser Supremo, Maa Ngala, criador de todas as coisas", tendo criado o ser humano porque "sentiu falta de um interlocutor"; assim, "criou o Primeiro Homem: Maa" (HAMPATÉ BÂ, 2010, p. 170, 
grifos do autor). Este último foi composto de um conjunto de forças, as quais ficam "em estado de repouso até o instante em que a fala venha colocá-las em movimento... A fala é, portanto, considerada como a materialização, ou a exteriorização, das vibrações das forças" (HAMPATÉ BÂ, 2010, p. 172). No caso da limpeza de Tuahir, não bastava o ramo de palmeira como algo que vinha de Kindzu, era necessária a força das palavras "faladas" por Muidinga.

Com o veículo parado, a palavra se torna dinâmica, visto que, sendo força, a fala "gera movimento e ritmo, e, portanto, vida e ação" (HAMPATÉ BÂ, 2010, p. 172). Enquanto o ônibus não transita devido, sobretudo, à guerra, os cadernos de Kindzu oralizados pela leitura é que geram movimento, fazendo parecer que viajam. O romance se caracteriza pela palavra, segundo Moraes $(2009$, p. 56), pela "leitura em voz alta do testemunho de uma vítima da guerra", leitura que "move a terra, possibilitando que Muidinga e Tuahir empreendam viagem". O testemunho, como afirma Hampaté Bâ (2010, p. 168), "seja escrito ou oral, no fim não é mais que testemunho humano, e vale o que vale o homem"; destaca-se, assim, "o próprio valor do homem que faz o testemunho, o valor da cadeia de transmissão da qual ele faz parte" (2010, p. 168).

Sobre essa "cadeia de transmissão" das tradições orais, ainda tomando por base o bambara, Hampaté Bâ explica que em "todos os ramos do conhecimento tradicional, a cadeia de transmissão se reveste de uma importância primordial", devendo ocorrer de modo regular para manter a "magia" e não se tornar "somente conversa", pois a "fala transmitida pela cadeia deve veicular, depois da transmissão original, uma força que a torna operante e sacramental" (HAMPATÉ BÂ, 2010, p. 181, grifos do autor). A palavra, portanto, é veículo; diante da guerra que paralisa os meios de transporte, como o machimbombo, a palavra de Kindzu veicula a experiência e, assim, gera outra forma de movimento.

Os cadernos de Kindzu são, fazendo-se uma aproximação com a perspectiva de Hampaté Bâ, uma forma de transmissão, mesmo sem a "magia", em que se destaca a experiência histórica, afastando-se um pouco da centralidade do conhecimento ancestral religioso veiculado nas tradições orais. Pois, mesmo que a narrativa de Kindzu se faça pela constante relação entre o real e o sonhado, que haja um conjunto de elementos advindos das tradições ancestrais, a guerra é a grande ameaça, o que causa a desordem e deixa o espaço em ruínas. Não podendo vencer a guerra ainda, como desejava, Kindzu transmite sua experiência, veicula seu testemunho por meio da palavra a Muidinga, ressituando o jovem no mundo como Gaspar. Como declara Moraes (2009, p. 163), "é a palavra que Kindzu emite ao morrer que produz, em Muidinga, um novo nascimento", propiciando a "conclusão de sua iniciação". Essa transmissão da palavra possibilita que o mais novo - talvez - siga lutando para pôr fim à guerra, o que fica em aberto no desfecho.

Se Hampaté Bâ, ao tratar da força e valor da palavra, está preocupado, acima de tudo, com formas de preservação das tradições orais, Couto o faz, de alguma forma, na escrita de suas obras. Vale ressaltar que, por diversas vezes, Couto falou a respeito do que seria o "poder divino da palavra", sua "vocação divina" que "não apenas nomeia mas que inventa e produz encantamento" (COUTO, 2011, p. 109 e 14, respectivamente). Enquanto a guerra causa a destruição e apresenta o risco de uma dissolução total, a palavra mostrase com uma força de perenidade, de permanência, até mesmo depois da morte, como no caso do velho Siqueleto. 
Em uma das saídas nas redondezas do ônibus, Tuahir e Muidinga encontram Siqueleto. O ancião captura-os em uma armadilha porque os queria semear, isto é, semear pessoas para recuperar aquele espaço em desordem. Enquanto fala, ele balança uma lata com os próprios dentes, como se fizesse uma música. Afirma, depois, que o "mal está nos dentes", que os arrancou porque são "os dentes que convidam a fome", que "nos dias de hoje, os filhos mordem as mães quando ainda estão no ventre" (COUTO, 2007, p. 66-67). Os problemas que se impõem no meio social são tão profundos que geram um desequilíbrio das atitudes, culminando muitas vezes em formas de autoflagelação. Podese entender, nesse caso, como uma ameaça às tradições orais, também, porque a retirada dos dentes interfere na fala.

Em determinado momento, Muidinga retira o braço por um buraco da armadilha, pega "um pau e escreve no chão" (COUTO, 2007, p. 69), o que atrai o interesse de Siqueleto. O ancião pergunta sobre os "desenhos", obtém como resposta que era o seu nome e emociona-se. Ele se ajoelha, "limpa em volta dos rabiscos", permanece "ali por tempos... sorrindo para o chão com sua boca desprovida de brancos", depois "trauteia uma canção. Parece rezar." (COUTO, 2007, p. 69). Na sequência, Siqueleto toma uma decisão, pede algo ao jovem, concluindo-se essa parte da narrativa:

O velho Siqueleto armaneja uma faca. [...] Solta Tuahir e Muidinga das redes. São conduzidos pelo mato, para lá do longe. Então, frente a uma grande árvore, Siqueleto ordena algo que o jovem não entende.

- Está mandar que escrevas o nome dele.

Passa-lhe o punhal. No tronco Muidinga grava letra por letra o nome do velho. Ele queria aquela árvore para parteira de outros Siqueletos, em fecundação de si. Embevecido, o velho passava os dedos pela casca da árvore. E ele diz:

- Agora podem-se ir embora. A aldeia vai continuar, já meu nome está no sangue da árvore.

Então ele mete o dedo no ouvido, vai enfiando mais e mais fundo até que sentem o surdo som de qualquer coisa se estourando. $O$ velho tira o dedo e um jorro de sangue repuxa da orelha. Ele se vai definhando, até se tornar do tamanho de uma semente. (COUTO, 2007, p. 69 , grifos do autor)

Siqueleto morre quando tem certeza de que a vida continuaria por meio da árvore com seu nome, vida essa de que ele faria parte ao retornar à terra como semente. Esse aspecto do morto que retorna, passando a viver nas árvores, converge com a perspectiva das tradições de vários povos africanos, mas há as tensões com a modernidade, com as mudanças sociais que ameaçam essas tradições. Por isso, Siqueleto morre quando obtém uma resposta, quando a palavra escrita, essa forma de modernidade, serve para garantir a permanência das tradições, antes de base oral; ele morre, portanto, quando percebe que a escrita na árvore possibilita manter as tradições vivas.

Para recuperar o espaço em desarmonia pela guerra, unem-se a palavra, a terra e a árvore. A produção e reprodução da vida pela terra mostram-se, principalmente, pela vegetação, destacando-se a árvore que, para grande parte das religiões africanas, é detentora da força vital. Sob essa perspectiva, considera-se que o ser humano, ao "morrer, quer dizer, ao abandonar a condição humana, regressa - em estado de 'semente' ou de 'espírito' - à árvore", isto é, os "homens reintegram-se na matriz universal, adquirem outra vez o estado de semente, voltam a tornar-se germes" (ELIADE, 2010, p. 245). A morte de Siqueleto, portanto, não representa a dissolução total, mas, sim, "um retorno à fonte de vida universal" (ELIADE, 2010, p. 245), como semente ele pode renascer. Esse era 
seu intento, semear pessoas para reproduzir a vida e refazer a sociedade, o que se contrapõe aos "semeadores" da guerra (COUTO, 2007, p. 132), aqueles que "semeavam" a morte, a destruição que não permitia a continuidade da vida.

Mas, se há rupturas que preocupam, as tradições podem se renovar na escrita, como percebeu o ancião. É nesse sentido, com a transferência do valor da palavra oral para a escrita, que se tem a "lição de Siqueleto", conforme Leite (2012, p. 177), havendo uma "implícita releitura da parábola bíblica do Semeador" (2012, p. 177). Na narrativa bíblica, também são semeadas pessoas e há o valor da palavra, as sementes que caem na terra boa são como as pessoas que levam adiante a palavra de Deus. Siqueleto, por sua vez, encanta-se ao descobrir a força da palavra escrita, que se juntou à força da árvore, finalmente tinha certeza de que a sociedade poderia se regenerar, renascer.

Da mesma maneira, a morte de Tuahir traz a ideia de uma continuidade. Ele pede para ser colocado em um barco e deixado no mar, o que Muidinga faz enquanto lê o último caderno de Kindzu. Como afirma Bachelard (1997, p. 75), essa partida sobre as águas é "como se a própria morte fosse uma substância, uma vida numa substância nova". Ao se colocar no barco de madeira, acumula-se com a força da árvore também, sendo que, para diversos povos, o momento da morte é como um retorno à fonte vital. A água traz a ideia de uma continuidade da vida, da morte como um renascer, pois como afirma Eliade (2010, p. 153), "a imersão na água", em diversos conjuntos culturais, "simboliza o regresso ao pré-formal, a regeneração total, um novo nascimento, porque uma imersão equivale a uma dissolução das formas, a uma reintegração no modo indiferenciado da preexistência". Soma-se a essa característica da água, no romance, a força da palavra, visto que a despedida se faz com a leitura do último caderno:

- Deixe. Agora me comece a ler.

As ondas vão subindo a duna e rodeiam a canoa. A voz do miúdo quase não se escuta, abafada pelo requebrar das vagas. Tuahir está deitado, olhando a água a chegar. Agora, já o barquinho balouça. Aos poucos se vai tornando leve como mulher ao sabor de carícia e se solta do colo da terra, já livre, navegável. Começa então a viagem de Tuahir para um mar cheio de infinitas fantasias. Nas ondas estão escritas mil estórias, dessas de embalar as crianças do inteiro mundo. (COUTO, 2007, p. 195-196, grifos do autor).

A morte é entendida como uma viagem, o morto retorna à fonte vital através da água e da árvore, mas também pelas narrativas. A continuidade da vida ocorre também pelas histórias, não apenas contadas, mas escritas e lidas, haja vista a transformação social da modernidade, a renovação das tradições. A aprendizagem de Muidinga, portanto, envolve essa "cadeia de transmissão" em que, lembrando Hampaté Bâ (2010), a palavra veicula uma força, sendo uma característica humana fundamental.

Para algumas sociedades negro-africanas, de acordo com Leite (1995-1996, p. 105), a palavra possui uma força maternal, manifestando-se primeiramente no ser humano "através da respiração" e assim, sendo transmitida, "interfere na existência". Desse modo, "o aparelho auditivo é assemelhado aos órgãos reprodutores femininos: ambos são capazes de fazer gestar algo decisivo pela penetração, no interior dos indivíduos, de um elemento vital" (LEITE, 1995-1996, p. 105). A palavra e sua transmissão, como acontece com os cadernos de Kindzu a Muidinga, somam-se à terra e à água, como forças produtoras de vida, esse conjunto materno com a potência de regenerar o espaço em ruínas. 
Dessa maneira, o mar segue como espaço, não apenas de "História", mas de "estórias", pois, entre acontecimentos verdadeiros e inventados, vale a transmissão, vale contar, como pede Muidinga uma vez: "Conte, tio. Se é uma estória me conte, nem importa se é verdade." (COUTO, 2007, p. 154). Daí que se tenham "mil estórias" de "embalar crianças", o que se reforça pelos atributos maternos da palavra e da água; Muidinga, então, terá a chance de um renascimento como Gaspar, já que lê o último caderno em que é feita essa revelação. Com a palavra transmitida por Kindzu, Muidinga redescobre sua identidade e, pela aprendizagem, pode continuar a luta pelo fim da guerra e recuperação do país.

\section{A palavra viva na forma}

Há, em Terra sonâmbula, como se nota, um processo de escrita com base nas tradições orais, não apenas na temática, mas, também, na forma. A organização do romance se dá pela leitura "oralizante" dos cadernos, sendo intercaladas duas narrativas, a de Tuahir e Muidinga, e a de Kindzu conforme seus cadernos. Ao mesmo tempo, são "encaixadas" outras histórias, geralmente contadas por alguma personagem, cujos sentidos se refletem ou se complementam às demais ou ao sentido global da obra. Por essa razão, com uma estrutura circular ou em espiral, o romance é considerado como "mise-en-abîme" (LEITE, 2012, p. 173; FONSECA; CURY, 2008, p. 117).

Para Obiechina (1992, p. 199), a "estória dentro da estória", denominada por ele de "provérbio narrativo", é uma característica do romance africano, sendo uma forma de reunir as tradições orais e a escrita literária ${ }^{1}$. Os escritores introduzem mitos, contos e canções da oralidade "dentro das matrizes de suas obras, no desenvolvimento de seus enredos e temas, e na formulação de seus princípios artísticos e formais", sendo chamadas de "provérbios narrativos" porque essas estórias encaixadas "assumem as funções orgânicas e estruturais de provérbios no discurso oral e na literatura" (OBIECHINA, 1992, p. 199). Embora esse aspecto seja encontrado em outras literaturas, o que Obiechina (1992) destaca é a sua recorrência na literatura africana, marcando os textos com transformações na estrutura advindas das formas das tradições orais. Esse processo entre oralidade e escrita, como tema e estrutura, é explorado ao máximo, como forma de construção de uma identidade:

Nessa perspectiva, a tematização da tradição - enquanto registro das diferentes acepções da oralidade, tanto as linguísticas quanto as temáticas, genealógicas e as culturais - deve ser entendida como uma demanda estratégica na qual os africanos se colocaram simultaneamente em relação a um ethos africano, bem como em relação ao resto do mundo. (LEITE, 2012, p. 165, grifo da autora).

Se há tradições orais pelo mundo, na África buscam-se as suas especificidades, isto é, embora possa haver semelhanças sobre esse aspecto em várias literaturas, nas africanas procuram-se destacar as diferenças. Esse processo entre oralidade e escrita, segundo Leite, envolve mais do que intertextualidade, havendo também a "relação intersemiótica entre sistemas", visto que além de textos, transitam "motivos, símbolos, gestos rituais e mesmo assunções inarticuladas que acompanham as execuções orais"

\footnotetext{
${ }^{1}$ Tradução livre.
} 
(LEITE, 2012, p. 166). Para Quayson, há uma "interdiscursividade", fazendo com que o texto literário seja "olhado já não como um espelho reprodutor de elementos culturais, mas, antes, como um campo prismático de interação entre discursos culturais e literários" (QUAYSON, 1997, apud LEITE, 2012, p. 166).

Como parte desse processo, em Terra sonâmbula (2007), há a "imbricação de gêneros", sendo que cada capítulo pode ser singularizado, tomado como "uma unidade fabular independente", como um "episódio-conto", de modo que "o romance é organizado como uma sequência de contos, ligados por coordenação e, simultaneamente, por encaixe" (LEITE, 2012, p. 170). A maior parte dos outros gêneros que adentram o romance, predominando a forma do conto, são as fábulas, parábolas e relatos pessoais, além de provérbios e sentenças em tom profético; são encaixados, assim, "especularmente" nas duas narrativas principais (LEITE, 2012, p. 171).

Há, desse modo, várias personagens que contam histórias, sejam relatos de experiências ou lendas. Como resultado dessa estrutura, entre outros aspectos, está a caracterização do país entre a História e as histórias; estas têm suas fronteiras questionadas, como o sonho e a realidade que se cruzam, o que está sugerido na temática do sonambulismo na obra. Essa temática é estrutural da narrativa, aproximando-se do que afirma Candido (1965) sobre a fusão de texto e contexto, do conteúdo que constitui a forma, gerando uma série de indefinições ou redefinições dos acontecimentos narrados. Surgem dúvidas entre o que teria sido sonho ou realidade, com a reversão de um em outro, havendo a reincidência de motivos, como bem explica Moraes (2009, p. 34-35):

O romance Terra sonâmbula opera, em seus diferentes níveis, do micro ao macro, desestabilizações nos sentidos supostamente esperados, desestabilizações que demandam do leitor novos arranjos semânticos. Como disse, a ressonância (pelas semelhanças) e a profusão (imagética e de narrativas) produzem, articuladas, nexos novos entre os elementos do texto, nexos que desviam seu andamento esperado (a linearidade narrativa) instaurando a reversibilidade e produzindo novos sentidos possíveis. [...] O fenômeno descrito ocorre de maneira ampla no romance, desde seu trabalho na língua até sua macroestrutura. Ocorrem repetições sonoras que demandam, por ressonância, a atenção à materialidade do signo. Ou seja, mesmo no âmbito fonético-morfológico, o romance produz abalos nas expectativas de linearidade, abalos que afetam as relações esperadas entre significante e significado, entre signo e sua referência, instaurando circularidade e auto-referencialidade.

Com essa forma, Couto provoca os leitores a saírem da passividade, deixando de ser meros receptores do texto escrito para experimentar a "vivacidade" do que é narrado, sendo estabelecido um jogo. Como segue explicando Moraes (2009, p. 35), há um "esgarçamento do fio condutor da narrativa", fazendo com que seus diferentes elementos "se soltem", produzindo "a suspensão de seus sentidos", mas sem instaurar "a fragmentação definitiva". O leitor, então, é convidado "a participar de um jogo de aproximações, a perseguir os pontos de costura amplamente armados no romance, tecendo-o em novos moldes", visto que a fragmentação ocorre "apenas na medida em que solta os elementos das relações esperadas", possibilitando a "construção de novos fios" (MORAES, 2009, p. 35-36).

\footnotetext{
${ }^{2}$ QUAYSON, A. Strategic Transformations in Nigerian Writing. Oxford: James Currey, 1997.
} 
Com esse conjunto que desafia e surpreende os leitores, dos neologismos, alterações em provérbios e expressões à estrutura narrativa mais geral, os textos de Couto remetem à distinção que alguns formalistas fazem entre a linguagem poética e a linguagem cotidiana, especialmente quanto à desautomatização. Na estrutura do texto artístico, como explica Lotman (1978, p. 137), "trabalham simultaneamente dois mecanismos opostos: um tende a submeter todos os elementos do texto ao sistema, a transformá-los numa gramática automatizada, sem a qual o acto de comunicação é impossível", enquanto "o outro tende a destruir essa automatização e a fazer da própria estrutura o portador da informação".

Esse aspecto foi discutido, antes, pelos formalistas russos para diferenciar o texto artístico do não artístico, em que o primeiro desautomatiza a linguagem, retirando-a do uso comum e banal do segundo. Para Chklovski (1976, p. 44-45), a linguagem cotidiana caracteriza-se por um "processo de automatização", em que haveria um "enfraquecimento" da percepção, enquanto a linguagem poética constrói-se na contramão disso, procurando "aumentar a dificuldade e a duração da percepção". Para o autor, ao exemplificar com a obra de Tolstoi, a automatização faz parecer que a vida desaparece, visto que se age sem a preocupação perceptiva, enquanto a literatura tem o potencial de "devolver a sensação de vida" com o "ato de percepção" prolongado (CHKLOVSKI, 1976, p. 44-45). A desautomatização, portanto, faz parte do jogo provocado por Couto em suas obras, tornando a palavra "viva".

Nesse sentido, sendo a metáfora um dos principais recursos de Couto, como a "terra sonâmbula", as "páginas de terra", o "rio/tempo", a "casa/terra", suas obras remetem à "metáfora viva" de Ricoeur (2005). Em seu amplo estudo, o autor a diferencia da "metáfora morta". Esta seria a que já se tornou comum, banal, o que se aproxima da linguagem cotidiana dos formalistas, enquanto a metáfora viva é aquela que se cria, caracterizando-se pela novidade, especialmente na literatura. A metáfora envolve uma tensão entre o sentido literal e o sentido figurado, isto é, "uma tensão cultivada pela contradição no plano literal"; quando ela se "desgasta", torna-se "morta", é porque essa tensão diminuiu ou desapareceu, já na "viva", "esta tensão é essencial", ela permanece (RICOEUR, 2005, p. 327). Para o autor, a metáfora está no cerne da renovação da linguagem, sobretudo a poética com "seu poder de abertura para novos aspectos, novas dimensões, novos horizontes da significação" (RICOEUR, 2005, p. 381).

Essa perspectiva remete a Bakhtin (2011), tanto pela "inovação" e surpresa na criação literária, quanto pelo aspecto humano da palavra, semelhante ao ponto de vista de Hampaté Bâ (2010). Segundo Machado (2010, p. 207), pautando-se em Bakhtin, "ser humano é significar, produzir sentidos na interação... o homem ocupa um lugar único na existência que só pode ser singularizado e definido distintivamente em relação ao outro com o qual interage dialogicamente".

Como na cadeia de transmissão, é por meio do diálogo que, para Bakhtin (2011, p. 348, grifos do autor), caracteriza-se o humano:

Natureza dialógica da consciência, natureza dialógica da própria vida humana. A única forma adequada de expressão verbal da autêntica vida do homem é o diálogo inconcluso. A vida é dialógica por natureza. Viver significa participar do diálogo: interrogar, ouvir, responder, concordar, etc. Nesse diálogo o homem participa inteiro e com toda a vida: com os olhos, os lábios, as mãos, a alma, o espírito, todo o corpo, os atos. Aplica-se 
totalmente na palavra, e essa palavra entra no tecido dialógico da vida humana, no simpósio universal.

Nota-se, portanto, uma relação entre linguagem e vida. No contexto da nação em guerra, o que gera um número grande de mortes, a palavra pode circular e ser regeneradora, o que Couto traz às suas obras tanto pela temática como na estrutura. Próximo ao desfecho de Terra sonâmbula, surge um feiticeiro que faz um longo discurso em tom profético, falando da desordem extrema no país e como poderia haver a recuperação. Segundo o personagem, surgiria uma voz para dar "a força de um novo princípio", desde que chegasse ao fim o tempo de guerra que os "fez animais", como ele conclui, apelando: "Deixai que morra o animal em que esta guerra nos converteu" (COUTO, 2007, p. 202, grifos do autor). Essa voz, de acordo com Moraes (2009, p. 159), tem um "caráter afirmativo e fundador", à qual, diante da "animalização (desumanização)", são "atribuídos poderes vitais, de refundação do humano".

Nesse momento que faz parte do último sonho de Kindzu, aproximando-se do "realismo animista" ${ }^{3}$, algumas personagens transformam-se em animais, ilustrando a desumanização causada pela guerra, processo que se conclui com a perda da capacidade comunicativa e da racionalidade: "A fala foi a última coisa a ser convertida [...]. Aos poucos, porém, também o verbo se perdeu" (COUTO, 2007, p. 202). Kindzu verifica se o mesmo the tinha acontecido, analisa a própria voz, emitindo "palavras simples" e, depois, frases, isto é, confirma sua humanidade pela palavra. Com a desumanização causada pela guerra, a palavra - oral e escrita, transmitida, realizando-se em diálogo - é um dos recursos para a reumanização.

Com a metáfora, as histórias encaixadas, a desautomatização, ao surpreender os leitores e provocar o jogo, Couto mostra a palavra como "viva", aproximando-se de outra forma do pensamento de Hampaté Bâ (2010), visto que, além de recriar as tradições orais ao escrever, utiliza outros recursos linguísticos. Apesar de não resistir à polissemia em todo o seu potencial, como explica Cavacas (1999, p. 16), indo do "mágico, mítico e simbólico mais incomum ao comezinho e quotidiano", o resultado que fica, com em um jogo de desconstrução e reconstrução, é a surpresa. Mesmo quando recorre aos "velhos" sentidos, é para trazer a tensão com os "novos", resultando nos abalos à linguagem, em certo grau de novidade e, assim, em "novos horizontes de significação" (cf. RICOEUR, 2005, p. 381). Com essa característica, reunindo as tradições literárias orais e escritas, africanas e estrangeiras, Couto evidencia a não fixidez da linguagem, seu caráter dinâmico, com as cadeias de transmissão em "diálogo inconcluso", como algo que confirma o humano, mostrando, assim, a "vivacidade" da palavra.

\footnotetext{
${ }^{3} \mathrm{O}$ "realismo animista", segundo Garuba, é uma característica de grande parte das obras literárias africanas e consiste, como o nome indica, em uma realidade permeada pelo animismo. Para o autor, nas sociedades africanas, há um "modo animista de pensamento" advindo das religiões ancestrais, mas que deixa de ser apenas religioso, sendo "incorporado ao âmbito dos processos de atividades materiais e econômicas" e que "se reproduz na esfera da cultura e da vida social, agindo "como uma força motriz na formação da subjetividade coletiva" (GARUBA, 2012, p. 241). Combatendo a ideia de que se trata de um "primitivismo", Garuba (2012, p. 242) mostra que é uma característica humana fortemente marcada na África, configurando-se como um "inconsciente animista", "uma forma de subjetividade coletiva que estrutura o ser e a consciência". Couto recorre a esse aspecto para representar a desumanização causada pela guerra, ressaltando-se que a temática geral da obra da personificação da terra com o sonambulismo envolve, também, a perspectiva animista.
} 


\section{Considerações finais}

As tradições, de modo geral, são a principal fonte e tema das obras de Mia Couto, mas sua posição é questionadora, trazendo as tensões com a modernidade. Converge, portanto, com a visão antiessencialista da cultura, considerada uma questão não "de ser, mas de se tornar" (HALL, 2003, p. 44). Também, está em consonância com Gilroy (2012, p. 29), autor que critica "a ideia de tradição mais como repetição invariante do que como estímulo para a inovação e a mudança". Para Couto (2011, p. 164), as tradições estão "em constante movimento", sendo dupla a sua preocupação. Há os casos insustentáveis, que não deveriam permanecer, como os que oprimem as mulheres. Em outras situações, há o risco das perdas culturais, de se deixar de lado o conhecimento ancestral.

Com as tradições orais recriadas na escrita, "atualizadas" nos romances, há um sentido de sua preservação. Segundo Couto, existe uma lógica da oralidade que vem sendo ameaçada pela hegemonia da escrita, sobretudo no meio rural, onde os "pressupostos filosóficos" próprios dessa lógica "correm o risco de serem excluídos e extintos" (COUTO, 2011, p. 102). O escritor, no entanto, não faz uma defesa pura e simples das tradições orais, afirmando que o mundo rural "necessita de enfrentar o confronto com a modernidade", que o "desafio seria alfabetizar sem que a riqueza da oralidade fosse eliminada", "ensinar a escrita a conversar com a oralidade" (COUTO, 2011, p. 103).

É uma situação aparentemente contraditória, uma vez que a escrita, de acordo com Chaves (1999, p. 206), configura-se como uma "quase traição às origens" ancestrais da oralidade, porém se faz necessária "em nome da defesa dessas mesmas origens, ameaçadas ainda e sempre da destruição total". As ameaças que eram, antes, do colonialismo e da guerra pós-Independência, passam a ser, depois, da globalização. Em face disso, os escritores africanos, preocupados, como Hampaté Bâ (2010) com as tradições orais em risco, fazem do texto africano, segundo Padilha (1995, p. 10), "um lugar outro, interseccional e liminar, situado entre voz e letra". A contradição se dá, não apenas pela diferença entre o oral e o escrito em si, mas, também, porque o autor escreve sobre e em um país que ainda tem milhões de não alfabetizados, buscando as "formas adequadas", como explica Cavacas (2006, p. 63), de contribuir com a construção da nação recém-independente:

A dificuldade desta adequação resulta da tentativa de fazer corresponder à oralidade criadora e genuína de culturas diferentes moçambicanas a escrita unificadora e normativa tradutora de uma cultura em que os moçambicanos se reconheçam/venham a se reconhecer. A esta escrita corresponde uma língua em mutação que parte de uma matriz europeia (a dos colonizadores) e vai tomando formas e matizes africanos, sem que a corrupção seja nem imitação propriamente dita, nem recriação caótica descomprometida.

No conteúdo e na forma, as obras de Couto possibilitam pensar a identidade nacional em formação, embora, ao mesmo tempo, apresentem características literárias extra-africanas. Esse aspecto identitário, no que tange ao processo entre oralidade e escrita, está representado do desfecho de Terra sonâmbula (2007), quando os cadernos escritos de Kindzu, após serem "oralizados" pelo jovem Muidinga ao ancião, transformam-se em "páginas de terra". Para a "nova" nação, a escrita é incontornável, mas precisa se fazer em diálogo com as tradições orais, como aconteceu com Tuahir e Muidinga, por meio de uma aprendizagem recíproca. 
Couto estabelece o diálogo - que, para Bakhtin (2011), pode envolver o confronto de posições ideológicas diferentes - entre as várias esferas e repertórios culturais, não deixando de pensar a moçambicanidade também com as tensões entre o local e o universal, entre o africano e o extra-africano. Em sua literatura, Couto reúne temas e formas da oralidade com as técnicas de escrita, realizando um trabalho com a linguagem que resulta - juntando as perspectivas de Hampaté Bâ (2010), Ricoeur (2005) e Bakhtin (2011) - em humanização, isto é, em fazer-se humano pela linguagem, especialmente pela criatividade, mostrando e confirmando a "palavra viva".

\section{REFERÊNCIAS}

BACHELARD, G. A Água e os Sonhos: ensaio sobre a imaginação da matéria. São Paulo: Martins Fontes, 1997.

BAKHTIN, M. M. Estética da Criação Verbal. 6. ed. São Paulo: WMF Martins Fontes, 2011.

CANDIDO, A. Literatura e sociedade: estudos de teoria e história literária. São Paulo: Companhia Editora Nacional, 1965.

CAVACAS, F. Mia Couto: Brincriação Vocabular. Lisboa: Mar Além, 1999.

Mia Couto: palavra oral de sabor quotidiano/palavra escrita de saber literário. In: CHAVES, R.; MACÊDO, T. C. (Org.). Marcas da diferença: as literaturas africanas de língua portuguesa. São Paulo: Alameda, 2006, p. 57-73.

CHAVES, R. A Formação do Romance Angolano: Entre Intenções e Gestos. São Paulo: Via Atlântica/USP, 1999.

CHKLOVSKI, V. A arte como procedimento. In: TOLEDO, D. de O. (Org.). Teoria da Literatura: formalistas russos. 3. ed. Porto Alegre: Globo, 1976. p. 39-56.

COUTO, M. E se Obama fosse africano? e outras interinvenções. Ensaios. São Paulo: Companhia das Letras, 2011.

. Venenos de Deus, Remédios do Diabo: as incuráveis vidas de Vila Cacimba. São Paulo: Companhia das Letras, 2010.

. Terra sonâmbula. São Paulo: Companhia das Letras, 2007.

Um rio chamado tempo, uma casa chamada terra. São Paulo: Companhia das Letras, 2003.

DURAND, G. As Estruturas Antropológicas do Imaginário: introdução à arquetipologia geral. 2. ed. São Paulo: Martins Fontes, 2001.

ELIADE, M. Tratado de História das Religiões. 4. ed. São Paulo: WMF Martins Fontes, 2010.

FONSECA, M. N. S. Velho e Velhice nas Literaturas Africanas de Língua Portuguesa Contemporâneas. In: BARBOSA, M. J. S. (Org.). Passo e compasso: nos ritmos do envelhecer. Porto Alegre: EDIPUCRS, 2003, p. 63-82.

FONSECA, M. N. S.; CURY, M. Z. F. Mia Couto: espaços ficcionais. Belo Horizonte: Autêntica, 2008. 
GARUBA, H. Explorações no realismo animista: notas sobre a leitura e a escrita da literatura, cultura e sociedade africana. In: Nonada Letras em Revista, Porto Alegre, a. 15 , n. 192012 , p. 235-256.

GILROY, P. O Atlântico negro: modernidade e dupla consciência. 2. ed. São Paulo/Rio de Janeiro: Editora 34/Universidade Candido Mendes/Centro de Estudos Afro-Asiáticos, 2012 .

HALL, S. Da Diáspora: identidades e mediações culturais. Belo Horizonte: Ed. UFMG/ UNESCO, 2003.

HAMPATÉ BÂ, A. A tradição viva. In: KI-ZERBO, J. (Ed.). História Geral da África: I - Metodologia e Pré-História da África. 2. ed. Brasília: UNESCO, 2010. p. 167-212.

LEITE, A. M. Oralidades \& escritas pós-coloniais: estudos sobre literaturas africanas. Rio de Janeiro: Ed. UERJ, 2012.

LEITE, F. Valores civilizatórios em sociedades negro-africanas. In: África: Revista do Centro de Estudos Africanos, São Paulo: USP, n. 18-19 (1), p. 103-118, 1995-1996.

LOTMAN, I. A Estrutura do Texto Artístico. Lisboa: Estampa, 1978.

MACHADO, I. A questão espaço-temporal em Bakhtin: cronotopia e exotopia. In: PAULA, L. de; STAFUZZA, G. (Org.). Círculo de Bakhtin: teoria inclassificável. Campinas: Mercado de Letras, 2010. p. 203-234.

MORAES, A. M. R. de. O inconsciente teórico: investigando estratégias interpretativas de Terra Sonâmbula, de Mia Couto. São Paulo: Annablume/FAPESP, 2009.

OBIECHINA, E. Narrative Proverbs in the African Novel. In: Oral Tradition, Columbia: Center for Studies in Oral Tradition, University of Missouri, v. 7, n. 2, p. 197-230, oct. 1992.

PADILHA, L. C. Entre Voz e Letra: o lugar da ancestralidade na ficção angolana do século XX. Niterói: Ed. UFF, 1995.

RICOEUR, P. A metáfora viva. 2. ed. São Paulo: Loyola, 2005.

Recebido em: 30/08/2016

Aprovado em: 27/07/2017 